\title{
A ENUNCIAÇÃO DE GOLPE: \\ HETEROGENEIDADE, POLÊMICA E INTERDISCURSO
}

\author{
EMANUEL ANGELO NASCIMENTO* \\ (UNICAMP)
FERNANDO SIMPLÍCIO DOS SANTOS ${ }^{* *}$
(UNICAMP)

ANDERSON AUGUSTO ROSZIK ${ }^{* * *}$

(USP)

\begin{abstract}
Resumo: Este artigo tem por objetivo discutir e analisar os processos de enunciação e as condições de produção do(s) sentido(s) em torno da palavra golpe, que circulou recentemente, na mídia brasileira, envolvendo o afastamento de Dilma Rousseff da presidência da República, no Brasil, em 2016. Para tanto, mobilizamos alguns dos pressupostos teóricos da Análise do Discurso (AD) de linha francesa, tendo como ponto de ancoragem teórico-analítica a questão da polêmica, além das noções de heterogeneidade enunciativa, a partir das reflexões de Authier-Revuz $(1982,1984)$ e de interdiscurso, a partir de Pêcheux (1975), em diálogo com as perspectivas enunciativas trabalhadas por Benveniste (2006 [1974]) e por Guimarães (2002). O corpus de análise é constituído de alguns textos publicados, entre 2015 e 2016, pelos jornais Folha de S. Paulo e O Estado de S. Paulo, a partir dos quais observamos a heterogeneidade discursiva nos processos de enunciação de golpe, buscando explicitar as constantes disputas e os deslocamentos de sentidos construídos sócio-históricamente, no interdiscurso, considerando as diferentes posições-sujeito e as Formações Discursivas (FDs) em jogo. Palavras-chave: Heterogeneidade enunciativa; Polêmica; Interdiscurso.
\end{abstract}

Résumé: Cet article vise à discuter et à analyser les processus d'énonciation et les conditions de production de(s) sens autour du terme coup, qui a circulé récemment dans les médias brésiliens, impliquant la suppression de Dilma Rousseff de la présidence de la République au Brésil en 2016. Par conséquent, nous avons mobilisé des hypothèses théoriques de l'analyse du discours française, en tenant compte comme point de repère théorique et analytique la question de la polémique, ainsi que des notions d'hétérogénéité énonciative, basée sur Authier-Revuz (1982, 1984), et de interdiscours, à partir des idées de Pêcheux (1975), en dialogue avec les perspectives énoncitives travaillées par Benveniste (2006 [1974]) et par Guimarães (2002). Le corpus d'analyse se compose de quelques textes et des énoncés publiés entre 2015 et 2016, dans les journaux Folha de S. Paulo et O Estado de S. Paulo, dans lesquels nous observons les bâtiments énonciatives et l'hétérogénéité discursive autour du terme coup,

* Mestrando em Linguística pelo Instituto de Estudos da Linguagem (IEL) da Universidade Estadual de Campinas (UNICAMP), Campinas, SP, Brasil, emanuellangelo@yahoo.com.br

${ }^{* *}$ Doutor em Teoria e História Literária pela Universidade Estadual de Campinas (UNICAMP), Campinas, SP, Brasil, fernandosimpliciosantos@gmail.com

*** Doutorando em Literatura Alemã pela Universidade de São Paulo (USP), São Paulo, SP, Brasil, aelroszik@gmail.com 
en cherchant à expliquer les conflits et les déplacements des sens construits socio-historiquement au interdiscours, par rapport aux différentes positions sujets et des formations discursives (FD) en jeu.

Mots clés: Hétérogénéité enunciative; Polémique; Interdiscours.

\section{INTRODUÇÃO}

O cenário político brasileiro, recentemente marcado por intensas manifestações sociais, polêmicas sobre casos de corrupção e conflitos políticopartidários, fez emergir, principalmente, na grande mídia, nas redes sociais e nos protestos das ruas, diversos discursos notadamente pró ou contra os recentes governos da ex-presidenta Dilma Rousseff e do ex-presidente Lula, ambos do Partido dos Trabalhadores (PT). Observam-se, geralmente, nestes discursos, as controvérsias, os posicionamentos ideológicos e a divergência entre classes sociais e forças políticas diferentes, algumas, eventualmente, mais populares e outras menos populares (ou mais elitistas), a partir das quais se evidenciam tanto uma crise política instaurada, no Brasil, como também diferentes confrontos políticoideológicos interpelados pela forte polarização entre esquerda e direita.

Em uma análise do pensamento político, no Brasil, o filósofo e historiador Norberto Bobbio, por exemplo, aponta que "o critério mais frequentemente adotado para distinguir a direita da esquerda é a diversa postura que os homens organizados em sociedade assumem diante do ideal da igualdade" (BOBBIO, 1994, p. 95). Tal como analisaremos, neste artigo, observamos que as esquerdas brasileiras, recentemente, passaram a acusar algumas forças políticas nacionais de tramarem um retrocesso frente às conquistas sociais possibilitadas pelo governo Lula e de perseguirem, consequentemente, o Partido dos Trabalhadores (PT), arquitetando um golpe contra o governo Dilma. Os apoiadores da direita, por sua vez, (chamados popularmente de "coxinhas" ${ }^{1}$ por muitos das esquerdas) redeslocam e disputam esse sentido da palavra golpe, afastando-a de si, colocando-a entre aspas e atribuindo-a ao outro. Como bem comenta Possenti (2016a), a palavra

${ }^{1}$ A palavra coxinha, usada como gíria, costumava, na década de 80, a ser empregada para designar policiais militares que, em intervalos de almoço, consumiam salgados (como coxinhas) nas lanchonetes da cidade de São Paulo, utilizando vale-refeições de baixos valores (chamados, posteriormente, de 'vale-coxinha'). Ao longo do tempo, 'policial' e 'coxinha' passaram a ser circular, em determinados espaços de dizer, como palavras 'sinônimas'. Em um trecho da letra de rap “Da Ponte Pra Cá”, de 2006, por exemplo, os Racionais MCs fazem essa referência de "coxinha” a policiais militares. Em 2002, entretanto, o publicitário Marcelo Costa, em um texto publicado na internet, utilizara o termo "coxinha" com um diferente sentido deste, explicando à Folha de S. Paulo, em matéria do dia 22/04/12, que já circulava em algumas tribos o adjetivo "coxinha" para se referir ao sujeito, geralmente, "mauricinho". Mais recentemente, no contexto de intensos protestos e manifestações políticas pelo país, o termo "coxinha" passou, geralmente no interior de determinadas Formações Discursivas (FDs), a designar pejorativamente uma pessoa considerada "certinha", "engomada", "arrumadinha" (eventualmente, um 'burguês'), de posturas e tendências políticas 'conservadoras', no sentido daquele que se opõe com vigor a ideias políticas ou econômicas, por exemplo, consideradas de esquerda. 
golpe, nesse caso e em outros, "é portadora de uma memória bastante negativa. Por isso, nem os golpistas gostam dela"'2.

Nessa perspectiva, mobilizamos alguns dos pressupostos teóricos da Análise do Discurso (AD) de linha francesa, levando em conta a questão da polêmica, além da noção de heterogeneidade enunciativa, a partir das reflexões de AuthierRevuz (1982, 1984) e da noção de interdiscurso a partir de Pêcheux (1975). Consideramos também a noção de memória discursiva a partir de Courtine (1981), a fim de dialogar com as perspectivas enunciativas trabalhadas por Benveniste (2006 [1974]) e por Guimarães (2002), trazendo, desse modo, para nossas análises a noção de enunciação enquanto acontecimento.

Nestes termos, levamos em conta o pensamento de Guimarães (2002, p. 11) de que "a enunciação, enquanto acontecimento de linguagem, se faz pelo funcionamento da língua". Assim, é a partir da língua e de seu funcionamento que procuramos observar como os sentidos da palavra golpe são construídos enunciativa e discursivamente.

Para tanto, procedemos à organização de um corpus constituído de alguns textos publicados, entre 2015 e 2016, pelos jornais Folha de S. Paulo e O Estado de S. Paulo, a partir dos quais observamos a circulação de diferentes enunciados em torno da palavra golpe, que se instaura(m) em um espaço, geralmente, interpelado pela polêmica.

Consideramos importante trazer para a discussão em torno do nosso objeto de estudo também os conceitos de heterogeneidade, a partir das reflexões de Authier-Revuz (1984), além da noção de interdiscurso, a partir dos postulados de Pêcheux (1975).

Em relação à heterogeneidade, levamos em conta, principalmente, as reflexões que Jacqueline Authier-Revuz apresenta em seu artigo "Hétérogénéité montrée et hétérogénéité constitutive, éléments pour une approche de l'autre dans le discours", ${ }^{3}$ publicado, em 1982, na França - a partir do qual a autora postula que a enunciação marcada pela heterogeneidade "se mostra constitutivamente atravessado pelos 'outros discursos' e pelo 'discurso do Outro"” (AUTHIERREVUZ, 2004 [1982], p.69). Afinal, para a autora, "o outro não é um objeto (exterior, do qual se fala), mas uma condição (constitutiva, para que se fale) do discurso de um sujeito falante que não é fonte-primeira desse discurso" (idem, p. 69).

Pensando a propósito disso é que trataremos, em um primeiro momento, de trazer para a as discussões o conceito de heterogeneidade enunciativa, tal como proposto pela autora. Em seguida, trabalharemos e desdobraremos nossas análises

${ }^{2}$ Sírio Possenti faz estas reflexões a partir de seu texto intitulado Golpe, Golpes, publicado, em 05/05/16, em seu blog. Neste texto, Possenti aborda algumas questões semânticas em torno da palavra golpe, considerando, por exemplo, a memória negativa que a palavra porta, principalmente, em relação ao Golpe de 1964, que, à época, foi chamado pelos representantes da ditadura de "Revolução de 64" (e não de golpe).

${ }^{3} \mathrm{O}$ artigo original aqui citado foi traduzido para o português e publicado na obra "Entre a transparência e a opacidade: um estudo enunciativo do sentido" (2004), sob o título "Heterogeneidade mostrada e heterogeneidade constitutiva: elementos para uma abordagem do outro no discurso". 
a partir das noções de polêmica, de interdiscurso e da questão da memória, principalmente em torno da palavra golpe.

\section{A QUESTÃO DA HETEROGENEIDADE ENUNCIATIVA}

Jacqueline Authier-Revuz iniciou os seus estudos na virada dos anos 60 e, desde 2009, é professora emérita da Universidade de Paris III. Linguista francesa, Authier-Revuz desenvolveu suas pesquisas sob um escopo teórico inscrito na Teoria da Enunciação filiada a Émile Benveniste, operando interface com outras áreas do conhecimento, tais como: a psicanálise de Freud e Lacan, a teoria bakhtiniana e a contribuições de Michel Pêcheux à Análise do Discurso francesa. Partindo das teorias psicanalíticas de descentramento do sujeito, do conceito de dialogismo, a partir dos preceitos do filósofo russo e estudioso da linguagem, Mikhail Bakhtin, os trabalhos de Authier-Revuz ganharam grande destaque teórico, nos estudos linguísticos, ao abordarem o conceito de heterogeneidade.

Authier-Revuz (2004 [1982]), em seu entendimento, considera que os discursos são, geralmente, atravessados por outros discursos - posto que por trás de uma aparente linearidade da enunciação ilusória de uma só voz outras vozes falam. Esta abordagem inicial permitiu que a autora francesa avançasse nas conceituações linguísticas, sob um viés enunciativo-discursivo, propondo, assim, uma importante distinção entre duas formas de heterogeneidade, a saber: a heterogeneidade mostrada (marcada ou não-marcada) e a heterogeneidade constitutiva do discurso.

A respeito da heterogeneidade constitutiva, a autora aponta, principalmente, para a condição pela qual as marcas linguísticas nem sempre explícitas são atravessadas pelo inconsciente, pelo interdiscurso e pela natureza dialógica dos sentidos. Partindo, portanto, desse pressuposto, Authier-Revuz (2004 [1982]) concebe a noção de heterogeneidade constitutiva do discurso como uma:

[...] ancoragem necessária no exterior do lingüístico: e isso, não somente para as formas que parecem oscilar facilmente devido às modalidades incertas de seu resgate, mas, fundamentalmente, para as formas mais explícitas, mais intencionais, mais delimitadas da presença do outro no discurso (idem, p. 22).

Por heterogeneidade mostrada (noção sobre a qual nos apoiaremos em nossa análise), entende-se "a presença do outro no discurso de um determinado locutor, ou seja, como alteridade que atravessa o fio de um determinado discurso, designando o outro no ato de enunciação", segundo Authier-Revuz (1990 [1982]) apud OLIVEIRA, 2008, p. 5). Cabe ressaltar, ainda, que, quando este outro é linguística e explicitamente detectável no enunciado, tem-se aquilo que Jacqueline Authier-Revuz caracteriza como heterogeneidade mostrada marcada. Nesse sentido, "a autora apresenta como exemplos a glosa, as aspas, o itálico, referências etc" (OLIVEIRA, 2008, p. 5).

No caso de a heterogeneidade mostrada não ser explicitamente detectável ou marcada (por aspas ou outros elementos) na materialidade do enunciado: 
[...] temos a heterogeneidade mostrada não marcada. Neste caso, a heterogeneidade aparece como "efeito de sentido de um dito que se articula a um não dito" (Authier-Revuz, apud Beck, 2008). É o que acontece no discurso indireto livre, na alusão, na imitação, na reminiscência etc (OLIVEIRA, 2008, p. 5).

Entre as diversas formas de heterogeneidade mostrada não-marcada, a exemplo do que comenta a autora, podemos citar também a ironia, os estereótipos, a alusão, os clichês e a imitação. Authier-Revuz (2004 [1982]), ainda, reflete que esses modos de enunciação são compreendidos pela presença do outro no enunciado, não explicitados por marcas unívocas, mas acessíveis pela exterioridade discursiva. Assim, de acordo com a autora, “a 'menção' que duplica 'o uso' que é feito das palavras só é dada a reconhecer, a interpretar, a partir de índices recuperáveis no discurso em função de seu exterior" (idem, p. 17-18).

\section{OLUGAR DAPOLÊMICA:DAENUNCIAÇÃOAOINTERDISCURSO}

Dentro dos estudos da AD, Maingueneau (1983, 2005 [1984]) postula que a polêmica corresponderia à própria condição de existência dos discursos no que diz respeito, mais propriamente, às formas de interincompreensão, dado que a relação com o outro, segundo o autor, é sempre constitutiva, perpassando relações, geralmente, antagônicas. A característica mais forte nessa relação interdiscursiva seria, justamente, a não-compreensão mútua entre aqueles que, eventualmente, constroem imagens um do outro e daqueles com os quais se encontram em relação de concorrência, levando em conta o funcionamento dos discursos e as forças ideológicas partilhadas ou não no interior das Formações Discursivas (FDs) em jogo. Assim, Dominique Maingueneau destaca que:

[...] quando se considera o espaço discursivo como rede de interação semântica, ele define um processo de interincompreensão generalizada, a própria condição de possibilidade das diversas posições enunciativas. Para elas, não há dissociação entre o fato de enunciar em conformidade com as regras de sua própria formação discursiva e de "não compreender" o sentido dos enunciados do Outro; são duas facetas do mesmo fenômeno. No modelo, isso se manifesta no fato de que cada discurso é delimitado por uma grade semântica que, em um mesmo movimento, funda o desentendimento recíproco (MAINGUENEAU, 2005 [1984], p. 99).

Outros aspectos importantes que Maingueneau ressalta, ao refletir sobre os processos de constituição da interincompreensão e da polêmica são, por exemplo, a controvérsia, o conflito e as relações de ameaça recíproca e generalizada. Para o autor:

[...] a controvérsia se desdobra em dois terrenos ao mesmo tempo. Cada discurso deve simultaneamente responder aos golpes que recebe e dar golpes; mas isso supõe duas séries de escolhas: - No conjunto de enunciados que lhe são dirigidos, o discurso responde àqueles que lhe parecem os mais ameaçadores (...) - Na massa frequentemente considerável dos enunciados não-polêmicos do Outro, o discurso define alguns pontos de ataque (idem, p. 109-110). 
Nesse sentido, o conflito estabelece um jogo em que "não adianta os protagonistas jurarem que dispensariam completamente o conflito, que eles só entram na disputa obrigados, porque, de fato, eles estão desde sempre envolvidos nela" (ibidem, p. 109) - bem como podemos identificar nos confrontos ideológicos entre esquerda e direita e nos discursos contra e pró-governo Dilma aqui discutidos. Como muito bem reflete Orlandi (1990, p. 86), o discurso polêmico é "aquele em que a polissemia é controlada, o referente é disputado pelos interlocutores, e estes se mantêm em presença, numa relação tensa de disputa pelos sentidos" a partir dos processos de enunciação e de discursividade.

Em uma perspectiva enunciativa, Guimarães (2002, p. 18) afirma que "os espaços de enunciação são espaços de funcionamento de línguas, que se dividem, redividem, se misturam, desfazem, transformam por uma disputa incessante". Nesse sentido, observa-se aquilo que toma conta da própria condição de possibilidade das diversas posições enunciativas. Não haveria, a princípio, dissociação entre o fato de enunciar em conformidade com as regras de uma dada formação discursiva $(\mathrm{FD})^{4}$ - enquanto aquilo que, segundo Pêcheux (1988 [1975]), pode e deve ser dito a partir de uma posição dada numa conjuntura dada) e, por outro lado, em relação ao fato de "não compreender" o sentido dos enunciados do Outro. São como diferentes facetas de um mesmo fenômeno. Isso se manifestaria no fato de que cada discurso se inscreve em movimentos que fundam o desentendimento recíproco.

Mobilizando, assim, a polêmica instaurada recentemente, no Brasil, em torno dos sentidos de golpe, os processos de interincompreensão interpelam fortemente a polarização entre esquerda e direita, em uma disputa acirrada pelos sentidos. Nesse entendimento, consideramos, inicialmente, as reflexões de Bobbio (1994):

a contraposição entre direita e esquerda representa um típico modo de pensar por díades, a respeito do qual já foram apresentadas as mais diversas explicações [...] Existem díades em que os dois termos são antitéticos, outras em que são complementares [...] Além do mais, como já foi diversas vezes demonstrado, não há nada mais ideológico do que a afirmação de que as ideologias estão em crise. Reduzi-las a pura expressão do pensamento ideológico seria uma indevida simplificação. "Esquerda" e "direita" indicam programas contrapostos com relação a diversos problemas cuja solução pertence habitualmente à ação política, contrastes não só de idéias, mas também de interesses e de valorações [valutazioni] a respeito da direção a ser seguida pela sociedade (BOBBIO, 1994, p. 32-33).

${ }^{4}$ Michel Pêcheux absorveu a noção foucaultiana de formação discursiva e desenvolveu uma concepção mais alinhada ao materialismo. Relacionando essa noção diretamente com a de formação ideológica, em uma formação social dada, Pêcheux (1975) identifica um modo de produção específico que a domina e um estado de relações de classe que a compõe, entretanto, reformula esse entendimento, ao refletir que os sentidos que uma FD pode prover são dependentes do interdiscurso, sendo neste lugar que se constituem os objetos que os sujeitos falantes se apropriam na construção de seus enunciados. Posteriormente, ainda, Pêcheux (1983), assumindo a impossibilidade de limitar o discurso a uma visão de estrutura fechada, a noção de formação discursiva, tendo um trajeto específico como ferramenta de análise, passa a se relacionar tanto com as condições de produção quanto com a questão do Outro e da heterogeneidade constitutiva do discurso enquanto lugar de dispersão mais que de uniformidade, sendo, por exemplo, uma FD atravessada por várias FDs. 
Nesse aspecto, o conflito ideológico entre estes dois pólos estabelece relações fortes de interincompreensão, marcadas, sobretudo, pela polêmica. Nesses e em muitos outros casos, observamos os modos de se enunciar a palavra golpe, na inscrição e no atravessamento do outro em um dado discurso - fazendo evocar um determinado conceito de interdiscurso.

Considerando, pois, a heterogeneidade das/nas relações entre a direita e a esquerda, tendo em vista o atual cenário político brasileiro envolvendo, de um lado, investigações sobre casos de corrupção no país e, de outro, o processo em torno do afastamento da presidenta Dilma, julgamos imprescindível mobilizar um dos conceitos de interdiscurso desenvolvidos no interior da $\mathrm{AD}$, partindo das reflexões especialmente feitas por Pêcheux (1975).

Inicialmente, em uma de suas teses, especificamente sobre a noção de formação discursiva (sobra a qual discorreremos na nota de rodapé anterior), Pêcheux (1975) propõe chamar de interdiscurso:

a esse "todo complexo com dominante" das formações discursivas, esclarecendo que também ele é submetido à lei de desigualdade-contradição-subordinação que [...] caracteriza o complexo das formações ideológicas (PÊCHEUX, 1988 [1975], p. 162).

Ao insistir em dizer que uma FD depende desse complexo com dominante como interdiscurso, Pêcheux destaca, assim, a objetividade material contraditória do interdiscurso, apontando que "o funcionamento da Ideologia em geral como interpelação dos indivíduos em sujeitos [...] se realiza através do complexo das formações ideológicas (e, especificamente, através do interdiscurso intrincado nesse complexo)" (PÊCHEUX, 1988 [1975], p. 162).

Tendo isso em vista, procuramos observar o lugar da polêmica no espaço enunciativo e no interdiscurso enquanto objeto que mais nos interessa aqui, neste artigo, considerando, principalmente, que, no recente cenário político brasileiro, os lugares de enunciação têm sido atravessados por constantes disputas ideológicas em torno do sentido daquilo que vem ou não a representar um impeachment ou um golpe, uma divulgação ou um vazamento seletivo de escutas telefônicas, um coxinha ou um petralha - mobilizando sentidos que se materializam no campo da polêmica e são produzidos na região do interdiscurso.

Desse modo, quando examinamos os enunciados em torno do processo de afastamento da presidenta Dilma Rousseff, identificamos expressões como golpe de Estado, conspiração e fraude, interrupção ilegal e usurpadora, ação inconstitucional para se referir ao impeachment, colocando em jogo sentidos que, em geral, estabelecem uma relação de polêmica no confronto com outros enunciados - a exemplo daqueles favoráveis ao afastamento da presidenta. Neste último caso, a palavra impeachment interpela sentidos associados a todo um processo de "legalidade", isto é, de "cumprimento" das leis e da constituição; enquanto para aqueles (pró Dilma) esse processo é visto como um rasgo, uma afronta à Constituição por se considerar não haver crime algum contra ela (presidenta). Assim, quando a palavra golpe é empregada entre aspas coloca-se em suspense se realmente houve ou não um golpe político no Brasil, no processo contra Dilma, em 2016. Sentido este mobilizado no interior, por exemplo, de 
determinadas FDS, tais como no discurso antipetista (e, em geral, no discurso engendrado contra as esquerdas), ao passo que para os militantes de esquerda (notadamente pró-PT) o golpe (sem aspas) direciona as coordenadas do sentido (sem colocá-lo em suspense ou em dúvida) apontando, no caso, para a crença reiterada e categórica de que este golpe representa um processo político ilegal, uma espécie de trama e de fraude.

Dito em outras palavras, os enunciados pró impeachment para um petista colocam no confronto ideológico o discurso do outro (dos conservadores, dos golpistas, dos coxinhas). Os enunciados que interpelam recorrentemente a expressão do "não ao golpe", para um tucano ou um psdbista, por exemplo, simbolizam o discurso rival (dos petralhas, dos lulopetistas, dos esquerdistas). Como bem assinala Authier-Revuz (1990 [1984], p. 27), "nenhuma palavra é 'neutra', mas inevitavelmente 'carregada', 'ocupada', 'habitada', 'atravessada' pelos discursos nos quais 'viveu sua existência socialmente sustentada"”.

\section{A PALAVRA GOLPE E O LUGAR DA MEMÓRIA}

A memória, tal como reflete muito bem Orlandi (1990, p.31), é tratada, assim, na perspectiva do interdiscurso e corresponde ao "saber discursivo que torna possível todo dizer e que retorna sob a forma do pré-construído, o já-dito que está na base do dizível, sustentando cada tomada da palavra". Eni Orlandi, nesse sentido, mobiliza, em suas reflexões, importantes conceitos como o de interdiscurso, aqui já comentado, o de pré-construído, elaborado por Henry (1975) e desenvolvido posteriormente por Pêcheux (1975) e o de memória discursiva, tal como foi formulado, em 1981, por Jean-Jacques Courtine.

A propósito da noção de pré-construido, Paul Henry, em 1975, propôs esse conceito para dar conta da presença do outro nos fios do dizer correspondente, em outros termos, àquilo que ele próprio chama de "effet subjectif d'antériorité, d'implicitement admis" 5 (HENRY, 1975, p. 97), para se referir ao sentido que "remete a uma construção anterior, exterior, mas sempre independente, em oposição ao que é 'construído" pelo enunciado' (HENRY, 1975 apud PÊCHEUX, 1975, p. 99). O autor, ao refletir ${ }^{6}$ sobre essa conceituação, destaca também que:

[...] o que se diz, o que se escuta, é sempre atravessado por algo que já foi dito, atravessado por um dito anterior [...] O discurso não funciona de modo isolado, ele está sempre ligado a outros discursos que se convocam, que são convocados por sua letra, sua materialidade. É isso que levou à ideia de pré-construído, de início com um trabalho sobre a pressuposição tal como desenvolvido por Frege, mas nós nos distanciamos disso muito rapidamente, porque, simplesmente, a ideia de conteúdo de Frege consistia em que podia haver ao menos dois níveis em um texto - o nível superficial e algo que estava em uma posição segunda, se preferir, enganchada na primeira (Paul Henry, em entrevista ao Jornal da Unicamp, n. 587, 16 a 31 de dezembro de 2003).

${ }^{5}$ Em português, "efeito subjetivo de anterioridade, de implicitude admitida" (tradução nossa).

${ }^{6}$ As reflexões de Paul Henry aqui transcritas foram publicadas na entrevista $O$ discurso não funciona de modo isolado, feita por José Horta Júnior e publicada no Jornal da Unicamp, n. 587, 16 a 31 de dezembro de 2003. 
J-J. Courtine, por sua vez, em 1981, a partir de sua obra Analyse du discours politique: le discours communiste adressé aux chrétiens, concebeu a noção de memória discursiva, afastando-se de "toda memorização psicológica [...] cuja medida cronométrica os psicolinguistas se dedicam a produzir". Assim, Courtine (2009 [1981]) postula que:

[...] a memória discursiva diz respeito à existência histórica do enunciado no interior de práticas discursivas regradas por aparelhos ideológicos; ela visa o que Foucault (1971, p. 24) levanta a propósito dos textos religiosos, jurídicos, literários, científicos, "discursos que original um certo número de novos atos, de palavras que os retomam,ostransformamou falam deles, enfim, os discursos que indefinidamente, para além de sua formulação, são ditos, permanecem ditos e estão ainda a dizer" (COURTINE, 2009 [1981], p. 105-106).

O que nos chama a atenção, nesses conceitos desenvolvidos por Paul Henry, Michel Pêcheux e J-J Courtine e na relação entre o pré-construído e a memória discursiva, é essa existência histórica do enunciado que evoca um já-dito antes e em outro lugar. Assim, quando em diferentes posições-sujeitos um psdbista (eleitor, senador, deputado) atribui a um petista "o velho discurso da divisão entre nós e eles" ou eventualmente o chama de "mensaleiro" (e, em contrapartida, partindo de diferentes posições-sujeito, um petista designa o outro psdbista de tucano burguês, de coxinha ou de golpista), observamos que a palavra é portadora de toda uma memória e evoca todo um pré-construído, um já-dito antes e alhures.

Nesse caso, sintagmas como "nós e eles" (e suas variações - "divisão entre nós e eles", "velho discurso da divisão entre nós e eles"), atribuídos ao outro, evocam uma memória recente, que tem como referência, por exemplo, para um psdebista, o discurso político assumido pela então presidenta Dilma Rousseff, durante as eleições de 2014, na diferenciação entre os apoiadores e os opositores da esquerda. Certamente que, por razões políticas e históricas, um petista ou um militante de esquerda, dado o atravessamento ideológico mobilizado a partir de suas posições-sujeito dominadas por uma determinada FD, poderá negar esse discurso "da divisão entre nós e eles", atribuindo-o às elites (burguesas, psdebistas, tucanas) sob o argumento, por exemplo, de que estas elitas é que contribuíram politicamente, durante décadas para o aumento das desigualdades sociais existentes no país.

A interdiscursividade, desse modo, se materializa na relação de polêmica a partir da qual é possível identificar diversos deslocamentos e disputas de sentido em que a ideologia é interpelada e atravessada pela linguagem, pela relação entre sujeitos, enunciados, discursos e FDs em condições sócio-históricas determinantes. Analisando, assim, as condições de produção de certos enunciados em torno do afastamento da presidenta Dilma Rousseff, observamos como os sentidos e os discursos se materializam, segundo Pêcheux (1975):

[...] numa formação ideológica dada, isto é, a partir de uma posição dada numa conjuntura dada, determinada pelo estado de luta de classes, determina o que pode e deve ser dito (articulado sob a forma de uma arenga, de um sermão, de um panfleto, de uma exposição, de um programa, etc.) (PÊCHEUX, 1988 [1975], p. 147). 
Sendo assim, a luta de classes travada entre antigolpistas e pró-impeachment, entre esquerda e direita, no Brasil, é estabelecida pela disputa de sentidos que se constroem dada a natureza histórica dos acontecimentos e dado o lugar da polêmica instaurado no interdiscurso, à medida que determinado discurso se vê diante da ameaça do discurso do outro, no confronto ideológico estabelecido por uma relação conflituosa entre diferentes FDs e diferentes formações ideológicas.

Não raro, é no interdiscurso que a memória e o pré-construído são mobilizados, remetendo a uma exterioridade discursiva, a partir da qual, por exemplo, "coxinha" se relaciona à memória relativamente recente de palavras e de expressões como "mauricinho", "burguês", "conservador de direita", enquanto "mensaleiro" faz referência a todo um episódio, que ficou conhecido no Brasil, a partir de 2005, como o Escândalo do Mensalão, que veio à tona no discurso das mídias e envolveu diversas figuras políticas conhecidas no país, em esquemas de propina e corrupção - bem como aqueles nos quais também se encontraram envolvidos o senador Aécio Neves do PSDB e membros do alto escalão do PMDB, dentre eles, por exemplo, o deputado federal Eduardo Cunha, o senador Renan Calheiros, o ex-presidente José Sarney e Michel Temer, alguns destes delatados, na Operação Lava-Jato, pelo ex-presidente da Transpetro, Sérgio Machado, e por outros delatores, seja o operador financeiro Lúcio Funaro, seja os irmãos Wesley e Joesley Batista, empresários, donos da JBS.

Dessa maneira, muitos políticos citados do alto escalão PMDB e do PSDB incluem-se, no discurso mobilizado pelas esquerdas, dentre aqueles aos quais são frequentemente chamados de golpistas. Por exemplo, para um petista - enquanto sujeito dominado por uma determinada FD - tais golpistas são vistos como aqueles envolvidos em uma trama anticonstitucional para derrubar a presidenta Dilma, o que representa, no interior dessa FD, uma espécie de ameaça de um possível retrocesso político de muitas conquistas sociais possibilitadas pelo governo do PT.

A palavra golpe, nesse sentido, circula significando diferentemente, considerando as diferentes posições-sujeitos interpeladas no interior destas FDs em jogo. Um enunciado produzido por um militante pró-Dilma, pró-Lula e próPT em que aparece a palavra golpe, em geral sem aspas, interpela todo um modo determinado de significar modo e de atribuir ao outro (então denominado como golpista) certos sentidos. A palavra, assim empregada, pelos mobiliza toda uma memória política e histórica em torno dos sentidos de golpe.

Por outro lado, enunciados produzidos pelos sujeitos contrários ao governo Dilma e contrário às esquerdas, no Brasil, buscam redeslocar o sentido de golpe, deslizando-o para outros sentidos produzidos no acontecimento enunciativo. $\mathrm{O}$ uso das aspas, por exemplo, é um modo todo particular de enunciar que inscreve no interdiscurso a questão da dúvida.

Assim, tal como destaca Fuchs (1985):

[...] o enunciado opõe-se à enunciação como o produto à produção, objeto ao ato; mas a característica das problemáticas enunciativas reside precisamente no fato de que elas postulam a necessidade de referir-se à produção para dar conta do produto, na medida em que o produto contém os traços de sua produção. Se conhecemos apenas os enunciados, é a partir desses enunciados que se tenta inferir os mecanismos da enunciação (FUCHS, 1985, p. 121). 
Nesses termos, os processos em torno da enunciação de golpe incidem inevitavelmente sobre uma gama de diversos enunciados produzidos ao longo da história a partir dos sentidos de golpe.

\subsection{A memória do golpe de 64}

Na introdução de $O$ regime de 1964: discurso e ideologia ${ }^{7}$, obra de 1988, o linguista José Luiz Fiorin, de acordo com Brait (2015, p. 19-20), "refere-se ao fatídico ano de 1964, à tomada do poder pelos militares e à inconsequente repressão, instaurada via tortura e censura de um lado e de outro por meio do bombardeio à sociedade com o discurso oficial, militar, do poder". Assim, a memória negativa de 64, na história do Brasil, é interpelada com frequência por diversos discursos que buscam se afastar daquele projeto ditatorial armado que insurgiu como uma ruptura política de força abrupta e truculenta como forma de tomada do poder.

No interior de diversas Formações Discursivas (FDs), aquele movimento político representou um golpe contra a democracia, tanto que a ele, não raro, são associadas com larga frequência expressões e palavras como ditadura, regime ditatorial e/ou golpe de 64 - embora, por outro lado, os discursos defensores daquele movimento, mais comumente, se refiram a ele como revolução de 64 e/ou regime militar de 1964-1985.

Desse modo, ao longo da história, diversos dizeres frequentemente retomam ou evocam a memória negativa de 64, alguns dos quais, por exemplo, a obra publicada a partir da própria tese de doutorado de Fiorin (1988a [1983]), que aqui citamos. Outros dizeres, por sua vez, atualizam a memória do golpe de 64 ressignificando-a e redeslocadando-a, por exemplo, para o cenário político recente, tal como podemos identificar nesse trecho do artigo de opinião $O$ dia da infâmia, de Fernando Morais, publicado na Folha de S. Paulo (06/12/15):

"Minha geração testemunhou o que eu acreditava ter sido o episódio mais infame da história do Congresso. Na madrugada de 2 de abril de 1964, o senador Auro de Moura Andrade declarou vaga a Presidência da República, sob o falso pretexto de que João Goulart teria deixado o país, consumando o golpe que nos levou a 21 anos de ditadura [...] No crepúsculo deste 2 de dezembro, um patético descendente dos golpistas de 64 deu início ao processo de impeachment da presidente Dilma"

(Fernando Morais, Folha de S. Paulo, 06/12/15, grifos nossos)

Esse exemplo corrobora aquilo que Fiorin (1988b, p. 77) aponta sobre o fato de que a compreensão de um discurso relaciona-se com "a formação ideológica que o governa", considerando que "o itinerário pelo discurso não se esgota no interior do próprio discurso, mas se projeta na história” (idem, p. 77).

Retornando à análise da palavra golpe, atravessada que é por uma memória negativa do regime de 64 circulando no interior de determinadas FDs, observamos

${ }^{7}$ Obra então publicada a partir da tese de doutorado em Linguística defendida por José Luiz Fiorin, em 1983, junto à Faculdade de Filosofia, Letras e Ciências Humanas (FFLCH) da Universidade de São Paulo (SP), e intitulada A religião da imanência: uma leitura de discursos presidenciais (19641978). 
o aspecto disfórico em torno de seu(s) sentido(s). Possenti (2016c), por exemplo, destaca muito bem que "um dos efeitos do sentido prototípico de golpe leva a entender implicitamente golpe como golpe militar (eventualmente violento, com suspensão de direitos), como alguns enunciadores fazem" (idem, p. 1089), tratando-se, então, de uma palavra:

[...] fortemente negativa, disfórica. Ninguém assume que dá um golpe ou que é golpista. Um bom exemplo são os discursos em torno do golpe de 1964, cujos defensores o chamavam de "revolução" (até "revolução gloriosa", eventualmente reduzida a "gloriosa", com uma dose de ironia, na boca de críticos) e cujos adversários o chamavam de "golpe" ou "golpe militar" (ibidem, p. 1090).

Assim, enuncia-se golpe a partir de diferentes posições-sujeitos dominadas por FDs que permitem com que o seu sentido se desloque, deslizando para outros sentidos que significam diferentemente dadas as suas condições de produção. Nesse sentido, Fiorin (1988a, p. 129) afirma, por exemplo, que "dá-se uma valoração negativa a determinadas palavras que não poderiam ser usadas no universo "revolucionário"'. O autor, ainda, reflete que:

[...] o discurso "revolucionário" está em relação dialógica com o discurso de seus oponentes. Essa relação dialógica é de natureza polêmica. À medida que o sistema semântico sobre o qual repousam os discursos "revolucionários" está fundado sobre uma oposição generalizada ao sistema dos discursos "não-revolucionários", nenhum elemento escapa à relação polêmica [...] todo enunciado narrativo e todo tema do discurso "revolucionário" negam o enunciado e o tema correspondentes, atestado ou não, do discurso contrário (FIORIN, 1988a, p. 129).

Essas reflexões de Fiorin ancoram-se, como se observa, na ideia de que uma mesma palavra (no caso, golpe) pode estar presente em discursos opostos, porém, é lida de modo diferente, dado o atravessamento ideológico que perpassem diferentes FDs. Tais reflexões encontram ressonâncias nas palavras de Orlandi (1990), quando a autora afirma que:

[...] os dizeres não são, como dissemos, apenas mensagens a serem decodificadas. São efeitos de sentidos que são produzidos em condições determinadas e que estão de alguma forma presente no modo como se diz, deixando vestígios [...] Esse sentidos têm a ver com o que é dito ali mas também em outros lugares, assim como com o que não é dito, e com o que poderia ser dito e não foi. Desse modo, as margens do dizer [...] também fazem parte dele (ORLANDI, 1990, p. 30).

Essas importantes reflexões de Eni Orlandi a respeito de diferentes formas de dizer compreendem também, no movimento dos sentidos, as formas do silenciamento e do não-dizer. Assim, tal como analisa Possenti (2016b), "os que dizem que se trata de golpe não dizem que o impedimento não está previsto" - posto que, nos fios do discurso, as pressuposições, as implicitudes, o dito e o não-dito são instaurados enunciativa e discursivamente. Nesse sentido, a discursividade e as relações de polêmica (entre aqueles que defendem e aqueles que refutam a tese do golpe contra o governo Dilma Rousseff) são estabelecidas por formas mais ou menos implícitas de dizer e não-dizer, por exemplo, se houve ou não legalidade no impeachment ou se o processo contra Dilma representou ou não um golpe. Mais 
do que isso: os sentidos se movimentam atravessados que são pela memória e pela ideologia. Assim, trazemos para discussão, por exemplo, a questão da memória de 64, interessando-nos, desse modo, refletir sobre os possíveis sentidos de golpe e as tentativas de apagamento e silenciamento de sentidos outros produzidos no interdiscurso (em geral, sentidos estes associados à ideia de um regime ou processo político violento, torturador, repressor). Tal como assinala Fiorin (1988a):

[...] em 1964 assistimos no Brasil a um movimento militar que depôs o presidente da República e deflagrou uma intensa repressão em todos os setores da sociedade. A repressão exerceu-se em dois níveis complementares. Num primeiro, procurou-se eliminar a contestação ao regime por meio da tortura, das prisões, das cassações, da triagem ideológica, da intervenção nos sindicatos, etc. Num outro, tentou-se ocultar da sociedade, pela censura, tanto a verdadeira natureza do regime como os sinais de oposição ao estado de coisas implantado no país. Ao mesmo tempo, bombardeou-se a sociedade com um discurso oficial que pretendia ser a verdadeira "leitura" da realidade (FIORIN, 1988a, p. 1).

Feitas essas considerações, pretendemos a partir daqui discutir e analisar os processos de enunciação de golpe, colocando em confronto diferentes posiçõessujeitos dominadas por diferentes FDs e formações ideológicas, analisando as possíveis flutuações de sentido da palavra golpe, produzidas no interdiscurso e no atual cenário político brasileiro.

\section{2. Polêmica e semântica em torno da palavra golpe}

Falar em golpe, em termos de enunciação e discurso, pressupõe um exame minucioso e cuidadoso por parte do analista, uma vez que as palavras não são neutras, tampouco destituídas de uma vinculação com os sujeitos, com a linguagem e com a história. As palavras são, por assim dizer, portadoras de uma memória construída sócio-históricamente no interior e no exterior específico da relação entre determinadas FDs, sendo, portanto, portadoras de sentidos interpelados pela ideologia, pelas não-coincidências do dizer e pela contradição da materialidade linguística significante, bem como do trabalho com o simbólico produzido no interdiscurso e atravessado pela não-transparência da linguagem.

Caber destacar, nesse aspecto, as reflexões feitas por Authier-Revuz (2004 [1982]) sobre a opacidade da linguagem, posto que a autora oportunamente cita as palavras de Pêcheux, extraídas do capítulo Discours et Idéologie(s) da obra Les Vérités de La Palice, a propósito da condição de que:

[...] "o sentido" de uma palavra, de uma expressão, de uma proposição, etc. não existe "em si mesmo" (isto é, em uma relação transparente na literalidade do significante), mas é determinado pelas posições ideológicas colocadas em jogo no processo sócio-histórico, em que palavras, expressões e proposições são produzidas (isto é, reproduzidas); [...] as palavras, expressões, proposições... recebem seu sentido da formação discursiva a que pertencem (PÊCHEUX, 1975 apud AUTHIER-REVUZ, 2004 [1982], p. 37).

Com base nestas reflexões, procuramos observar, portanto, a nãotransparência do sentido, bem o caráter não-absoluto da palavra, a partir da análise das flutuações da palavra golpe em diversos campos e domínios. 
Tomamos, inicialmente, como base algumas propostas feitas por Possenti (2016a, 2016b, 2016c) sobre a circulação e a semântica de golpe, discutidas, assim, também por Portela (2016) e Aguiar (2004).

Partindo inicialmente da circulação de golpe, em especial no campo político, consideramos estes apontamentos de Possenti (2016b), que reflete que:

[...] alguns disfarçam sua posição dizendo, um tanto simploriamente (e alguns são ministros do Supremo!) que: a) se está previsto na Constituição e b) se for aplicado seguindo as regras definidas pelo Supremo, então não é golpe. Os que dizem que se trata de golpe não dizem que o impedimento não está previsto. Seu discurso é outro: o crime alegado não aconteceu (POSSENTI, 2016b, no texto Golpe?, publicado no blog do Sírio, em 07.04.16).

Sírio Possenti, nessas considerações, coloca em evidência o posicionamento e os argumentos mobilizados por aqueles que consideram que o processo de afastamento da presidenta Dilma "não é golpe". Procurando observar o funcionamento da polêmica, consideradas as condições de produção dos discursos assumidos no interior das FDs em jogo, Possenti (2016b) comenta que aqueles que refutam essa tese do golpe, (dentre os quais alguns ministros do Supremo Tribunal Federal (STF), apoiam-se, por exemplo, em um discurso jurídico específico que defende que "se está previsto na Constituição" e "se for aplicado seguindo as regras definidas pelo Supremo", então, esse processo não representa um golpe. Por outro lado, Possenti (2016) destaca que aqueles o consideram um golpe mobilizam, entre outros argumentos, o de que o crime ao qual se atribui à presidenta Dilma Rousseff não ocorreu, assim como nem todo esbarrão ou disputa de jogo é considerado(a) falta/ motivo de penalidade (tomando uma comparação do futebol feita por Juca Kfouri).

A palavra golpe aqui, tal como evidencia, Possenti (2016), é portadora de uma memória negativa relativamente recente na história do Brasil e, geralmente, é associada ao sentido negativo do golpe de 1964. Assim, até mesmo aqueles eventualmente acusados ${ }^{8}$ de tramar e arquitetar o golpe procuram rejeitar esta palavra, afastando-a de si.

Nesse ponto, considerando as recusas, o afastamento e a negação de determinados sentidos construídos sócio-historicamente, bem como as formas de silenciamento produzidas no interdiscurso, Aguiar (2004) comenta que:

[...] atestamos a presença de tais hábitos com a designação na imprensa que fala dos 40 anos do golpe como "Movimento Militar". Essa expressão nasceu para evitar a palavra "golpe", visada pela censura, e não ceder diante da "Revolução de 64", exigida pelo regime. Depois, com o início da restauração democrática em 85, a expressão "Movimento" foi posta de lado, liberandose o "golpe". Pois agora a expressão "Movimento" retorna, desta vez manipulada por uma imprensa talvez temerosa de ofender brios e pelos saudosos do golpe. O "Movimento Militar" agora aponta para um significado de que os golpistas atenderam a um "chamado da nação" (AGUIAR, 2004, em A semântica do golpe, publicado em Carta Maior, 30.03.04).

Posto que FDs e formações ideológicas conflitantes inscrevem-se nesse jogo polêmico e interdiscursivo de disputa pelos sentidos do que vem ou não a ser

\footnotetext{
${ }^{8}$ A partir de enunciados que circulam no interior de discursos antigolpistas.
} 
um golpe, tomamos aqui um exemplo em que podemos observar essa questão apontada por Flávio Aguiar no que diz respeito às tentativas de silenciamento e negação do sentido político de golpe, tal como no discurso adotado por algumas autoridades institucionais (a exemplo dos argumentos defendidos por José Celso de Mello Filho, ministro do STF, e por Carlos Ayres Britto, ex-presidente do STF e ex-professor assistente de Michel Temer, na área de direito constitucional). Assim, tal como afirmou, Ayres Britto, "não há que se falar em golpe caso o processo de impeachment avance, desde que respeitadas as garantias para a defesa da presidente [...] 'Toda previsão constitucional pré-exclui a possibilidade de golpe"” (Folha de S. Paulo, 24/03/16, grifos nossos).

Em 20/04/16, em seu Caderno de Política, o jornal O Estado de S. Paulo publicou a seguinte matéria 'Dilma comete 'gravíssimo equívoco' ao chamar impeachment de golpe, diz decano do STF”' (grifos nossos), a partir da qual insere no título da matéria a palavra do ministro Celso de Mello - evidenciando traços de uma heterogeneidade mostrada marcada. Desse modo, a expressão "chamar impeachment de golpe" não é uma fala a princípio do ministro Celso de Melo, mas uma referência à fala de Dilma. Trata-se aqui da questão do discurso outro presente em um determinado discurso e um modo de enunciar dos sujeitos.

No caso, o comentário feito por Celso de Mello diante da possibilidade de a presidenta abordar a tese do golpe durante pronunciamento em cerimônia de assinatura do Acordo de Paris sobre o clima, em 22/04/16, na sede da Organização das Nações Unidas (ONU), em Nova York (EUA), não apenas é destacado entre "aspas" pelo jornal, mas, funciona, discursivamente, como forma de reforçar a crítica feita por Celso em relação à Dilma e àqueles que mobilizam um determinado sentido (político) de golpe.

Observando esses casos aqui analisados, lembramos-nos das palavras de Guimarães (2003), para quem o sentido é o efeito de discurso no acontecimento do dizer, tendo em vista que cada ato enunciativo se constitui como um acontecimento, instaurado em um momento histórico específico, inaugurando um tempo próprio do discurso. Mais do que isso: "o sujeito não é assim a origem do tempo da linguagem. O sujeito é tomado na temporalidade do acontecimento" de acordo com Guimarães (2002, p. 12).

Por outro lado, também compreendemos como o acontecimento enunciativo é tomado pelos modos de enunciar dos sujeitos, que, de certo modo, se articulam àquilo que Benveniste (2006 [1974]) nos lembra a respeito da relação entre sujeito, discurso enunciação, uma vez que "a linguagem é, pois, a possibilidade da subjetividade, pelo fato de conter sempre as formas linguísticas apropriadas à sua expressão; e o discurso provoca a emergência da subjetividade" (BENVENISTE, 2006 [1974], p. 289). Além disso, Benveniste também chama a atenção para o fato de que "cada vez no seio de uma narrativa histórica aparece um discurso, quando o historiador, por exemplo, reproduz as palavras de uma personagem ou intervém, ele próprio, para julgar os acontecimentos referidos" (BENVENISTE, 2006 [1974], p. 267).

Assim, nas palavras do ministro do Supremo Tribunal Federal Celso de Mello, a presidente comete "gravíssimo equívoco" ao se referir ao processo de 
impeachment como um possível golpe em curso no Brasil. Dadas as posições político-partidária historicamente assumidas pelo jornal $O$ Estado de S. Paulo contra o governo do PT, esse mecanismo de destacabilidade e ênfase, por sua vez, à fala de Celso de Mello, funciona como forma de reforçar um discurso que encontra lugar em uma enunciação que, nas implicitudes, produz um efeito de sentido destinado a silenciar, abafar, inibir a tese do golpe (ou de colocá-la entre aspas, colocando-a em dúvida). Tomemos aqui emprestadas as palavras de Orlandi (1992, p. 52), quando a autora comenta sobre o pensamento de Lyotard (1983), afirmando que:

a frase que substitui o silêncio seria uma negativa [...] que se formularia assim: [...] b) esse caso não existe", sendo que, neste caso, "a política do silêncio se define pelo fato de que ao dizer algo apagamos necessariamente outros sentidos possíveis [...] indesejáveis, em uma situação discursiva dada (ORLANDI, 1992 p. 73).

Isto nos permite compreender, por exemplo, como Dilma, ao enunciar a palavra golpe (de forma incisiva) em um evento da ONU, produzira, entre tantos efeitos de sentido, o de ameaça no interior de determinada FD. Por sua vez, tratar do sentido golpe designando-o como "gravíssimo equívoco", como se observa nos modos de enunciar de Celso de Mello, não apenas produz um efeito de recusa da tese do golpe, mas deixa, a partir desse enunciado, rastros de uma tentativa de sufocar ou inibir um determinado discurso.

Esse tipo de mecanismo discursivo, cujo funcionamento se estrutura em uma política de silenciamento do dizer do outro (enquanto forma de censurar determinados sentidos) se articula a todo um modo estratégico de enunciar, defendo esta ou aquela tese, refutando outra(s). Isso pode, igualmente, ser examinado na recente polêmica envolvendo a ex-presidenta Dilma Rousseff e o ministro da Educação, Mendonça Filho, do governo Temer.

"Dilma afirmou, nas redes sociais, que 'censurar, agora, uma disciplina na UNB que caracteriza como golpe o processo inaugurado pelo impeachment, em 2016, deixa evidente o aprofundamento do arbítrio e da censura (...)"”

(Fórum de leitores, portal Estadao.com.br, 28/02/18, grifos nossos)

$\mathrm{O}$ comentário de Dilma se estrutura como crítica à tentativa do ministro Mendonça Filho de suspender o oferecimento da disciplina Tópicos especiais em Ciência Política: O golpe de 2016 e o futuro da democracia no Brasil, oferecida curso de graduação em Ciência Política da UnB. Defende que houve um golpe contra o seu governo, enquanto Mendonça Filho rebate Dilma afirmando não se tratar de "uma questão de opinião, nem de reverberar a tese petista sobre o impeachment de Dilma" (Estadao.com.br, 01/03/18). Aqui Mendonça trata do golpe sem citá-lo explicitamente, se referindo, pois, a ele como tese petista.

A partir disso, identificamos como não apenas os políticos, mas também as mídias, no cenário recente, deixam rastros, em seus modos de enunciar, sobre uma possível inconveniência da palavra golpe. Ou seja, na disputa político-ideológica entre esquerda e direita, notamos como essas forças "trabalham continuamente o dizer, de tal modo que todo discurso se faz nessa tensão: entre o mesmo e o 
diferente" (ORLANDI, 1990, p. 36). É nessa relação tensiva que notamos, por exemplo, alguns dos sentidos mobilizados enunciativa e discursivamente, como na matéria "Deputados entram com ação no STF para que Dilma explique por que chama impeachment de golpe”, do jornal O Estado de S. Paulo (05/05/16):

"Dilma e seus aliados adotaram o discurso de "golpe" para combater o impeachment. A
presidente já fez declarações neste sentido em vários discursos públicos, inclusive durante
cerimônias oficiais no Palácio do Planalto. Diversos ministros do STF já rebateram esse
argumento, ao afirmarem que o processo de afastamento de Dilma seguiu o que manda a
Constituição" (Caderno de Política, jornal O Estado de S. Paulo, 05/05/16, grifos nossos)

O posicionamento político-partidário historicamente assumido pelo jornal $O$ Estado de S. Paulo em favor deste e não daquele partido pode ser observado, nos fios do discurso, pela forma como a notícia é construída e o os enunciados são articulados enunciativamente, destacando a palavra golpe entre aspas (colocando o seu sentido em suspense, em dúvida), além de, nos fios do dizer, enfatizar o lugar ocupado por alguns ([...] "diversos ministros do STF”) em detrimento da imagem que se constrói daqueles cujos lugares políticos, dentre os quais o posto de presidente(a) da República, sequer são mencionados (referindo-se apenas a "Dilma e seus aliados". Mais do que isso: destaca-se alguns (aqueles contrários à tese do golpe) explicitando não apenas suas posições-sujeito (ministros do STF), mas também um dos argumentos: "o processo de afastamento de Dilma seguiu o que manda a Constituição", segundo tais sujeitos. Por outro lado, observe-se, não apenas o lugar ocupado por Dilma deixa de ser mencionado, como também o seu argumento sequer é citado pelo jornal, que em seus modos de enunciar destaca, assim, os dizeres de uns e silencia (apaga) os dizeres de outros. $O$ Estado de $S$. Paulo, assim, neste caso, apenas afirma que "Dilma e seus aliados adotaram o discurso do 'golpe', para combater o impeachment".

O jornal, portanto, dissimula e não explicita o(s) argumento(s) de Dilma afinal, como afirma Possenti (2016b), "os que dizem que se trata de golpe não dizem que o impedimento não está previsto. Seu discurso é outro: o crime alegado não aconteceu". Esse argumento defendido no interior do discurso pró-Dilma é, portanto, silenciado, ou seja, sequer é citado pelo jornal - cujas posições políticoideológicas podem ser evidenciadas em alguns de seus editoriais, tais como estes em que se destacam as nominalizações, os sintagmas e as atribuições de palavras semantica e ideologicamente negativas, por exemplo, em relação aos representantes políticos do PT: "O projeto totalitário do PT" $(22 / 05 / 16)$, "O populismo no banco dos réus" (07/05/16), “A ameaça petista” (18/04/16), "Quem Dilma convence?" (08/02/16), "Dilma e as amarras do passado" [08/01/16], "Lula, o informante" (27/12/15), "O vale-tudo de Dilma" (14/12/15), "Lula arma a cena para 2018" $(15 / 02 / 15)$. É nessa perspectiva que o jornal se alinha à ideologia política de direita e se inscreve na polêmica da semântica em torno do golpe, ao assumir determinados sentidos em torno desta palavra:

"Com o jogo praticamente perdido, a tigrada não hesitará em abraçar causas que lhe deem alguma vantagem na disputa pela opinião pública, mesmo que sejam inexequíveis, como é 
o caso da antecipação das eleições. Embusteiro por natureza, o lulopetismo já batizou a iniciativa de "Diretas Já", para comparar o atual momento à luta pelo fim do regime militar. É o típico golpe publicitário que prepara terreno para o golpe de fato. E gente que se diz de bem já encampa essa tese liberticida"

(Isso sim é golpe, editorial de O Estado de S. Paulo, 23/04/16, grifos nossos)

A partir de palavras de sema negativo (embusteiro) e empregadas de pejorativamente (a tigrada, o lulopetismo), a enunciação antipetista, no discurso assumido pelo editorial Isso sim é golpe, de O Estado de S. Paulo (23/04/16), também propõe colocar em jogo outros sentidos de golpe, acusando alguns de promoverem, por exemplo, um golpe publicitário.

Com efeito, um determinado enunciado se opõe, nesses casos, a outros, taid como àqueles que atribuem à tese do golpe outros sentidos, como, por exemplo, o de tese liberticida, mobilizado pelo argumento de que "gente que se diz de bem já encampa essa tese". Essa construção semântica de golpe aparece junto a expressões como "gente que se diz de bem", associadas a sentidos negativos, tais como o sentido empregado no uso do verbo encampar (no caso, aceitar como bom algo ruim).

Assim, nos fios do discurso, nega-se a tese do golpe apontada pelo discurso rival, mobilizando para isso estratégias enunciativas que funcionam como forma de não se submeter ao sentido aceito no interior de outra FD e visto, na relação interdiscursiva, como ameaça. Quando um enunciador afirma que "isto sim é golpe" e "golpe publicitário" isto pode representar, no interior de uma determinada FD, uma sequência enunciável, porém, no interior de outras FDs isto pode representar uma sequência não enunciável ou que, levando em conta as posições-sujeito, um enunciador eventualmente rival irá proferi-la, como bem reflete Possenti (2009, p. 156), "ponto-a à distância - marcando-a como sendo do Outro". Por exemplo, através do emprego das aspas (sinalizando para o que o outro diz ser golpe). Esses efeitos de distanciamento são percebidos, não raro, em muitos textos (escritos) que circulam socialmente, em diferentes espaços de dizer.

Durante o processo, em 2016, grande parte dos proferimentos de Dilma, enunciados a partir da posição-sujeito presidente(a), apontam para outro a responsabilidade pelo então golpe (político) em curso no país - como podemos observar em alguns textos da mídia:

"Em seu discurso mais incisivo desde que o processo de impeachment foi aberto na Câmara dos Deputados, na semana passada, a presidente Dilma Rousseff afirmou nesta terça-feira (22) que não 'renunciará de jeito nenhum' e se apropriou de um dos gritos mais comuns dentre as pessoas que defendem o seu governo ao afirmar ter certeza de que "não vai ter golpe""

(Folha de S. Paulo, 22/05/16, grifos nossos)

\footnotetext{
“"Nesse caso não cabem meias palavras, o que está em curso é um golpe contra a democracia. Eu jamais renunciarei. Pode se descrever um golpe com muitos nomes', afirmou Dilma ao participar de um ato de juristas, advogados, promotores e defensores públicos contrários ao seu impeachment em um evento no Palácio do Planalto. Ela foi fortemente aplaudida pelos convidados em diversos momentos"
}

(Folha de S. Paulo, 22/05/16, grifos nossos) 
"Não importa se o golpe é por um fuzil, vingança ou a vontade política de alguns de chegar mais rápido ao poder. Esse é o tipo de uso inadequado de palavras que se usava contra nós para dizer que não havia preso político no Brasil quando a gente vivia nas cadeias espalhadas pelo país', afirmou em referência ao período da ditadura militar"

(Folha de S. Paulo, 22/05/16, grifos nossos)

A Folha de S. Paulo tendo assumido, em seu editorial "Nem Dilma Nem Temer" (03/04/16), que o melhor caminho para a presidenta Dilma Rousseff, em meio ao cenário de político controverso, adverso e diante do clima de manifestações pelas ruas do país, seria o caminho da "renúncia", rompe em termos políticopartidários (e consequentemente ideológicos) com suas posições historicamente reconhecidas de esquerda. Assim, percebe-se também nos modos de enunciar como o veículo se distancia do discurso de apoio à Dilma, reijeitando-o de certo modo, ao afirmar que a presidente "se apropriou de um dos gritos mais comuns dentre as pessoas que defendem o seu governo", a saber: o grito "Não vai ter golpe!". Enquanto a Folha marca que esse é um discurso do outro (daqueles que defendem o governo Dilma), a então presidente, por sua vez, assume esse discurso (que também circula nas ruas), distanciando-se do discurso mobilizado pelos rivais e caracterizando-o como um discurso de "meias palavras". Dilma denuncia, assim, nos fios do discurso, "a vontade de alguns de chegar mais rápido ao poder" - fazendo alusão, nas implicitudes do dizer, à intenção de Temer e dos pmdbistas de assumirem o comando do país com o seu afastamento.

É nesse terreno que vamos observar, com base nas reflexões de Possenti (2009), que “o que 'pertence' a outra FD, mesmo fazendo parte do interdiscurso [...] só pode ser recusado, ironizado, parodiado" (idem, p. 156). Assim, os discursos da esquerda distanciam-se dos dizeres (ou dos gritos) "Fora, Dilma!" ou "Impeachment, já!", colocando em jogo, nesse sentido, a polêmica e a disputa semântica pela palavra, uma vez são atravessadas, no interdiscurso, pela ideologia e pela história.

Possenti (2016) propõe que "o fato de haver outras formas de designar golpes indica que se acredita [...] que há outros tipos de golpe - que são considerados golpes, analisados como golpes, embora não sejam golpes militares ou clássicos" (cf. figuras 1 e 2). O autor elenca, ainda, uma série de sentidos, alguns dicionarizados (outros não, porém, sócio-historicamente consagrados pelo uso - como é o caso de expressões como golpe branco e golpe militar). Essas reflexões ecoam nas palavras de Dilma, quando a então presidenta afirma que "pode se descrever um golpe com muitos nomes" (Folha de S. Paulo, 22/05/16), sendo que o golpe (nas palavras dela) pode ser "por um fuzil, vingança" ou pela "vontade política de alguns de chegar mais rápido ao poder”. Nesse sentido, segundo Portela (2016):

[...] vemos que em Brasília, na Universidade, nos corredores, nos botecos, o "golpe" desperta paixões e revela inauditas vocações, como o autoritarismo e o arrivismo, à esquerda e à direita [...] A palavra "golpe" é produtiva lexicalmente: "golpear", "golpeado", "golpismo", "golpista", "autogolpe". Em seu sentido político, desprendida do galicismo "golpe de Estado" ("coup d'État"), "golpe" ganhou uma autonomia relativa [...] Não é à toa que Eduardo Cunha, em entrevista recente a Mariana Godoy, da Rede TV, afirmou: "Pode ser que tenha tido um golpe no Brasil, mas foi um golpe de sorte". Vê-se que mesmo o chamado "arquiteto do golpe", destituído 
de sua função de presidente da Câmara dos Deputados, deixa-se levar pela "poética do golpe", na infâmia do trocadilho, por uma livre associação que não pode ser considerada exatamente livre (PORTELA, 2016, p. 2).

Podemos analisar brevemente, desse modo, as flutuações e os deslocamentos de sentidos em torno da palavra golpe em expressões e locuções adjetivas dicionarizadas ou não, bem como algumas formas consagradas pelo uso (cf. figuras 1 e 2). O que podemos identificar (cf. figura 1), em uma tentativa de representação das variações semânticas da palavra golpe mais comuns que circulam, geralmente, no interior de determinadas FDs no campo político, são as atribuições de sentido de golpe que alguns grupos (eventualmente, de esquerda ou de direita) atribuem remetendo ao discurso do outro. Nisso, podemos observar algumas variações morfossintático-semânticas de golpe, tais como: golpear, golpeado(a), golpismo (nominalização), golpista e antigolpista (adjetivações).

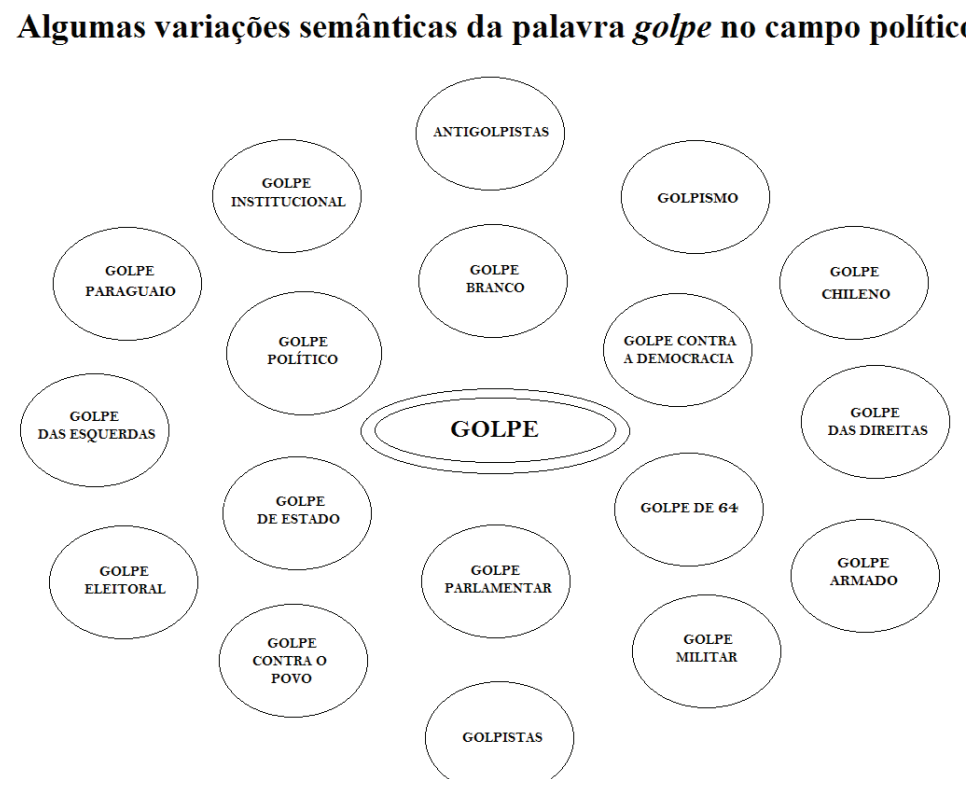

Figura 1. Algumas variações semânticas da palavra golpe (ilustração)

As análises feitas aqui buscam, portanto, apontar que há uma certa tendência geral, por exemplo, de os discursos de esquerda, em diferentes momentos da história e/ou mais recentemente nos discursos pró-governo Dilma, acusarem o outro (os de centro ou de direita) de articular ou apoiar, por exemplo: um possível golpe contra a democracia, um golpe militar, o golpe de 64, o golpe das direitas, entre outros sintagmas geralmente mobilizados.

Os grupos de direita e muitos daqueles contras as esquerdas (em geral, aqueles contra o PT e/ou contra o governo Dilma), por sua vez, têm mobilizado em seus discursos (em particular no cenário político brasileiro recente), golpes do 
tipo: golpe contra o povo (equivalente a golpe liberticida), golpe das esquerdas, golpe publicitário, golpe eleitoral - geralmente atribuídos aos petistas e aos apoiadores das esquerdas, pró-governo Dilma.

Entre alguns dos diversos termos distribuídos aleatoriamente na figura $1 \mathrm{e}$ mobilizados tanto pela esquerda como pela direita, em diferentes circunstâncias e momentos históricos, podemos identificar golpes do tipo: golpe político, golpe de Estado, golpe branco (termo usado na historiografia e na ciência política para se referir a uma conspiração ou trama visando à mudança de uma liderança política), golpe parlamentar, golpe institucional (cabendo aqui as ressaltas de que (i) a expressão golpe contra a democracia também circula no interior das FDs de direita sendo, às vezes, atribuído militantes da esquerda; (ii) esquerda e direita geralmente mencionam, com diferentes atribuições de sentido em seus discursos, o golpe chileno e o golpe paraguaio; (iii) a palavra golpista (também muito frequente e que circula muitas vezes com o sentido direcionado ora àqueles que praticam um golpe na praça, ora um estelionato, uma fraude ou um golpe político), embora rejeitado veementemente quando atribuído a si, foi/tem sido, no atual cenário do país, largamente empregada pela esquerda para se referir àqueles filiados aos discursos contra o PT e contra o governo Dilma; e (iv) o termo antigolpista, que, no interior de determinadas FDs (sejam elas de orientação político-partidária de esquerda, centro ou direita), dadas as condições sóciohistóricas, pode representar um sema positivo associado à ideia de "resistência" contra uma determinada força política impositiva, truculenta, antidemocrático e/ ou ilegal). Sobretudo, examinamos os diferentes empregos de golpe, considerando, nos termos de Guimarães (1996, p. 101), “a enunciação como o pôr-se a língua em funcionamento movimentada pelo interdiscurso, quando alguém ocupa aí uma posição de sujeito".

Assim, partindo do levantamento dos dados identificados em nossas análises, notamos uma variação semântica bastante ampla do termo golpe, circulando em diferentes campos. Nos registros dicionarizados ou não, a palavra golpe é com certa frequência empregada em diferentes locuções adjetivas, tais como (cf. figura 2): 


\section{Locuções adjetivas com a palavra golpe em diferentes campos}

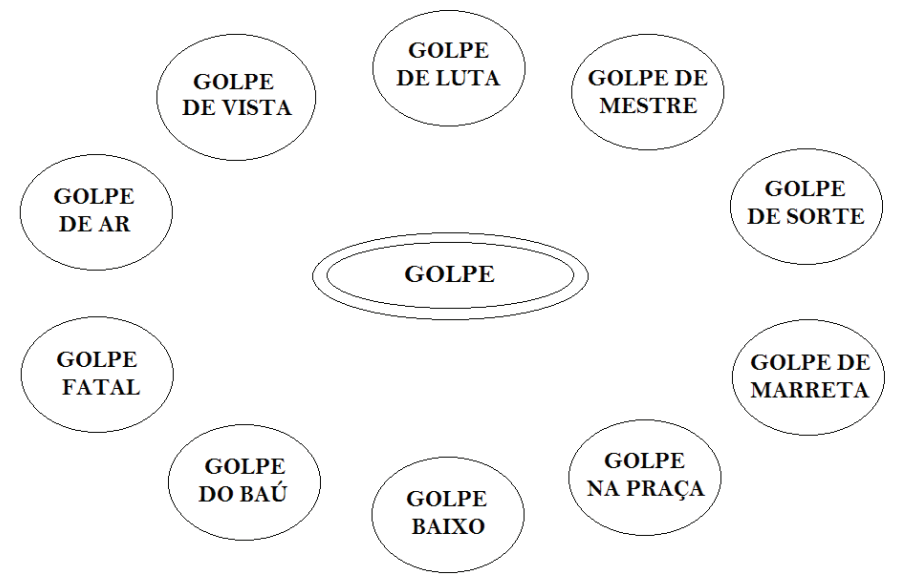

Figura 2. Locuções adjetivas com a palavra golpe em diferentes campos (ilustração)

Podemos comentar aqui, com eventuais contextualizações de uso, alguns destes termos em que, como se nota, os sentidos de golpe circulam em/por diferentes campos. Temos, entre alguns destes os de sema geralmente negativo, como: golpe na praça (em geral, associado à prática de uma trapaça, crime ou estelionato); golpe do baú (no sentido de engodo, para se conseguir, por exemplo, um casamento, eventualmente, por interesse financeiro); golpe baixo (geralmente relacionado a uma ação covarde; na luta, associado a um golpe físico proibido, desferido abaixo da cintura do adversário).

Há outros termos também como golpe fatal (equivalente a golpe de misericórdia ou a golpe certeiro, aplicado em algo ou alguém, geralmente, em estado moribundo, próximo da morte ou da falência); golpe de marreta (associado ao uso da marreta na construção civil para derrubar certa estrutura de prédio, casa, edifício, etc.); golpe de luta (associado, nas artes marciais, a golpe físico desferido contra o adversário, no boxe, no caratê, no judô, etc) e golpe de ar (equivalente, na geofísica e na meteorologia, a vento e/ou à corrente de ar).

Por outro lado, temos golpes portadores de sema eventualmente menos negativos (e às vezes positivos), como por exemplo em: golpe de vista (equivalente a um olhar rápido, olhar de relance); golpe mestre (utilizado no sentido tático de extrema habilidade, praticado com excelência e precisão; equivalente a golpe de gênio); golpe de sorte (geralmente súbito e cujo resultado é o de fortúnio, de boa ventura e/ou felicidade; sentido esse que circula e é disputado no interior de diferentes FDs, tal como foi mobilizado no campo político e ressignificado em termos político-ideológicos por meio da ironia, por exemplo, recentemente pelo deputado federal Eduardo Cunha [PMDB] para argumentar que "pode ser que tenha tido um golpe no Brasil, mas foi um golpe de sorte", se referindo, nas implicitudes do dizer, ao afastamento da presidenta Dilma Rousseff [em que sorte, 
nesse caso, é portador de um sema positivo para um e não para o outro]). Os traços semânticos de positividade ou negatividade sêmica (cabe oportunamente ressaltar) são de caráter geralmente relativo, pois deve-se levar em conta condições de produção do sentido (valores culturais, implicações, efeitos pragmáticos, resultados e consequências diversas), bem como a relação entre agente e receptor de determinado golpe. Assim, para aquele que é alvo de um golpe de mestre, seja na arte do xadrez ou em outro campo, provavelmente esse golpe não represente algo positivo, mas positivo o é para aquele que se sai vencedor, por exemplo, de um jogo ou partida - da mesma forma que um golpe de ar pode significar um vento forte que consequências trágicas e/ou catástroficas em/para uma determinada comunidade/localidade geográfica, não sendo, portanto, as palavras "neutras" de sentido. Tais considerações dialogam, em termos de uma semântica global, com as reflexões propostas por Portela (2016), que considera que:

[...] o "golpe", assim, intervém globalmente, é o motor da narrativa que produz a "intriga", no sentido de Paul Ricœur, produz reviravoltas, desfechos, muda o curso da ação e, portanto, o sentido partilhado por aqueles que agem [...] A dimensão conceitual, figurada, de "golpe" pode ser analisada como uma narrativa de privação: um sujeito age sobre o outro para the tomar algo que pensa ser (ou poder ser) seu ou de um terceiro. O sujeito do "golpe" pode ser motivado pelo querer-fazer ou pelo dever-fazer, sua motivação se configura segundo a finalidade da sua ação: querer ou dever ganhar, não querer ou não dever perder, querer ou dever apropriar-se, etc.

Nesse caso, as tentativas de mudança de curso ou de promover determinadas reviravoltas políticas no recente cenário brasileiro nos mostram como a palavra golpe se relaciona ou não com impeachment e com outras palavras como afastamento, impedimento e outras teses que surgiram durante esse processo que apontam para a palavra golpe variações de sentido - não necessariamente sinônimas ou correlatas no interior de uma ou outra FD. Assim, observam-se diferentes argumentos circulando socialmente para convalidar ou não a ideia de golpe: "Romero Jucá diz que ideia de eleições antecipadas é golpe" (Folha de $S$. Paulo, 05/04/16, grifos nossos) e a tese assumida pela presidenta Dilma, no interior do discurso antigolpista, de que "impeachment sem crime é golpe" (grifos nossos). Segundo Nascimento (2016), nesse ponto, observa-se que um discurso pode citar outro discurso:

[...] contrapondo ideologias diferentes, mesmo que em momentos e condições de produção diferentes. Não necessariamente, os textos que os materializam remetem explicitamente um ao outro, mas deixam, na implicitude do dizer, visões de mundo que ora se aproximam, ora se distanciam (NASCIMENTO, 2016, p. 347).

Na perspectiva assumida por Benveniste (1974), esse é, sobretudo, um processo enunciativo-discursivo, pois "o que em geral caracteriza a enunciação é a acentuação da relação discursiva com o parceiro, seja este real ou imaginado, individual ou coletivo" (BENVENISTE, 2006 [1974], p. 87). Assim, dado o caráter histórico-semântico em torno da palavra impeachment (portadora de uma memória negativa - relativamente recente, associada ao processo político, no Brasil, pelo qual passou o ex-presidente Fernando Affonso Collor de Mello, entre 
29 de setembro e 30 de dezembro de 1992), identificamos alguns processos de enunciação em que Dilma e os apoiadores de seu governo procuram também se afastar da ideia de impeachment, adotando em seu lugar (com grande frequência) a palavra golpe e impedimento; enquanto os opositores de Dilma, ao invés da palavra impedimento adotam, por exemplo, com mais frequência impeachment, afastamento, saída (e golpe, com um determinado sentido afastado de si e atribuído ao outro) - tal como se observa no enunciado do senador Romero Jucá (PMDB), em que ele defende que "a saída está na regra, está na Constituição [...] qualquer outra saída mirabolante, desculpem-me, aí sim é golpe" (Folha de S. Paulo, 05/04/16) e também como é observado na matéria "Para Barbosa, não há base para impedimento de Dilma", do jornal O Estado de S. Paulo (31/03/16) sobre a notícia de que, nos próprios dizeres do jornal, "o ministro da Fazenda, Nelson Barbosa, saiu em defesa da presidente Dilma Rousseff na comissão que julga o pedido de impeachment da presidente".

No caso da memória relacionada ao impeachment do ex-presidente Collor, em 1992, observamos que, enquanto as esquerdas recentemente procuram afastar de si o sentido negativo evocado por aquele acontecimento político-histórico, alguns discursos jurídicos, bem como os discursos contra o governo-Dilma, geralmente, evocam a memória do impeachment de Collor como referência e parâmetro do rito e dos procedimentos jurídicos adotados naquele processo (no âmbito tanto da Câmera dos Deputados Federais quanto no âmbito do Senado), atualizando-os para o cenário político recente - cabendo ressaltar aqui que a palavra golpe raramente foi mobilizada naquela ocasião de 1992 (salvo algumas exceções, como aquela em que o próprio Collor assumiu estar produzindo um livro intitulado Crônica de um golpe - a versão de quem viveu o fato, ainda não publicado). Nesse sentido:

[...] Pêcheux (1983a, p. 17) define o acontecimento discursivo como o "ponto de encontro de uma atualidade e uma memória". É um elemento descontínuo e exterior que afeta a memória produzindo ruptura e deslocamentos. Assim, pelo funcionamento da memória no acontecimento discursivo, os sentidos produzidos ao mesmo tempo repetem e deslocam o já-dito (ZOPPI FONTANA, 2004, p. 182).

Examinando o já dito, os pré-construídos e a memória em torno dos sentidos de golpe, na história política do Brasil, em relação à polêmica instaurada no recente cenário, os processos de significação a partir da enunciação enquanto acontecimento e a partir do próprio acontecimento discursivo em torno da ideia de golpe político, observamos como a palavra, discursivizada e posta em circulação, produz deslocamentos e coloca em jogo diferentes sentidos, que deslizam e se redeslocam, no movimento dos discursos.

Feitos estes importantes apontamentos e analisados alguns exemplos extraídos de enunciados que circulam na grande mídia, lembremos aqui oportunamente que outras palavras e expressões também de larga frequência no uso cotidiano da língua também são portadores de uma memória política construída nos rasgos da polêmica, assim como a palavra golpe. Este apontamento serve para que não nos esqueçamos de que as palavras justamente se colocam em constante movência, em deslocamentos e desdobramentos de sentido interpelados em diferentes processos 
enunciativos, pois, tal como afirma Benveniste (2006 [1974], p. 83), "a enunciação supõe a conversão individual da língua em discurso".

Nesse sentido, é que podemos compreender os processos de enunciação em torno da ideia de golpe, para além da marcação temporal, em que a história é percebida não como uma linha contínua representando uma grande narrativa marcada por um início, um ápice e um fim, mas observada, sim, como um redobramento heterogêneo de vários acontecimentos redistribuídos em zonas distintas. Como bem reflete Fiorin:

[...] os tempos, no discurso, fogem das rígidas convenções do sistema, mesclam-se, superpõemse, perseguem uns aos outros, servem de contraponto uns aos outros, afastam-se, aproximam-se, combinam-se, sucedem-se num imbricado jogo de articulações e de efeitos de sentido [...] como no contraponto, obedecem a regras, a coerções semânticas (FIORIN, 1996, p. 229).

Essas importantes considerações e reflexões de Fiorin sobre a dimensão temporal no cruzamento entre o enunciativo, o interior do discurso e a exterioridade discursiva dialogam, nesse entendimento, com o pensamento de Foucault a respeito da relação entre a história e o conceito de descontinuidade, um dos eixos fundamentais de sua obra, tomado como uma relação marcada pela imbricação e pelo jogo entre continuidades e descontinuidades. Afinal, para Foucault (2000 [1972], p. 273), “[...] a história não é, portanto, uma duração; é uma multiplicidade de tempos que se emaranham e se envolvem uns nos outros".

Levando em conta esse pensamento foucaultiano, entendemos como as tomadas e retomas de determinados dizeres ou de um discurso específico (seja sobre a memória do golpe de 64, seja sobre os enunciados produzidos recentemente, no Brasil, pela direita, pela esquerda e/ou pelo discurso antigolpista) são ressignificadas, no interdiscurso (i.e. no universo do dizível em relação às possibilidades do dizer), por meio da paráfrase, da polissemia e da reformulação em que os sentidos de golpe se atualizam a partir do/no acontecimento.

\section{CONSIDERAÇÕES FINAIS}

Ao cabo das análises e discussões propostas, neste artigo, em torno dos processos de enunciação em torno da palavra golpe relacionados ao afastamento da presidenta Dilma Rousseff, no Brasil, em 2016, procuramos observar como tais enunciados circulam nos discursos mobilizados pela esquerda e pela direita, bem como pelos grupos pró e contra o governo Dilma, funcionam no interior específico de diferentes Formações Discursivas (FDs), dadas as condições de produção do sentido, no interdiscurso.

Nesse caso, constatamos que o acontecimento enunciativo em torno do processo de afastamento da presidente repercutiu com expressividade na grande mídia, nas ruas e também nos textos que circulam nas redes sociais, estabelecendo relações de polêmica e conflitos político-partidários, a partir da mobilização de sentidos em torno de golpe, de impedimento, de petralhas, de coxinhas (além dos sentidos em torno de outras palavras e expressões aqui não analisadas, como 
bandidos de toga, grampo/interceptação, vazamento/divulgação, vazamento seletivo/publicização), que ora se afastam ou se aproximam, ora são aceitas ou rejeitadas - seja pela esquerda ou pela direita, seja pelos grupos pró ou contra o governo Dilma e, por conseguinte, pró ou contra o governo do Partido dos Trabalhadores (PT).

Essa forte polarização entre pró ou contra o governo, eventualmente, se deu pela adesão ou não ao processo político contra a presidente Dilma, o que também fez revelar, por exemplo, o posicionamento de outros grupos político-partidários como os de centro, centro-direita ou centro-esquerda, no fogo cruzado de apoio ou não à Dilma e/ou ao governo do PT.

Como ao analista pressupõe-se, entre outros desafios, a tarefa de tentar captar, no trabalho com a opacidade da linguagem, como as formulações de alguns enunciados se estruturam e deixam marcas ideológicas que marcam posições político-partidárias e que se colocam nas fronteiras do discurso. $\mathrm{O}$ recorrente emprego que se tem feito (ou não) das aspas, em torno da ideia ou não de golpe, no cenário em questão, serve, nesse sentido, para mostrar de que lado os sujeitos de discurso se posicionam politicamente.

Nesses termos, a enunciação se coloca como evento de aparição do enunciado. E dito de outra forma: aqueles que enunciam, por exemplo, que "impeachment é golpe" instauram o dizer a partir da aparição do enunciado em seu acontecimento, de forma que este acontecimento instala sua própria temporalidade. Para Guimarães:

[...] dois elementos são decisivos para a conceituação desse acontecimento de linguagem: a língua e o sujeito que se constitui pelo funcionamento da língua na qual enuncia-se algo. Por outro lado, um terceiro elemento decisivo, de meu ponto de vista, na constituição do acontecimento, é sua temporalidade. Não se trata aqui do contexto, da situação, tal como pensada na pragmática, por exemplo. Trata-se de uma materialidade histórica do real (GUIMARÃES, 2002, p. 11).

Assim, observamos de forma importante como determinados sentidos interpelados nos/pelos enunciados circulam na mídia apresentando-se marcados por traços de heterogeneidade em que, por exemplo, a partir das reflexões de Authier-Revuz (1982, 1984), é possível identificar rastros do discurso outro presentes em um dado enunciado. Alguns destes rastros apresentam-se, muitas vezes, de forma marcada ou não nos mecanismos de articulação enunciativa em torno da ideia de golpe (com aspas, para determinados grupos; e sem aspas, para outros). Trouxemos aqui algumas formas regidas pela destacabilidade, comum nos textos midiáticos, em que enunciados produzidos a partir da posição-sujeito deste ou daquele político (um senador, um ex-presidente/a, um ministro) ganham certo destaque nas manchetes de jornais e nos títulos das notícias.

Com efeito, não apenas trechos de falas do discurso outro, de pronunciamentos do outro foram destacados, mas também a memória foi constantemente evocada e atualizada no interdiscurso. Dito de outro modo, direita e esquerda, bem como os grupos prós e contra o governo Dilma, têm se colocado nas fronteiras do dizer ora aceitando ora recusando o golpe, ora se afastando ora se aproximando dele e, evocando sentidos pré-construídos, ditos antes e alhures. Nessas direções, muitos 
discursos em apoio à Dilma mobiliza(ra)m a enunciação (reiterada) do golpe como forma de luta, de resistência e de protesto contra uma determinada trama antidemocrática - enquanto aqueles que se posiciona(ra)m a favor do impeachment mobiliza(ra)m um discurso de rejeição da ideia de golpe, atribuindo-a ao outro, sinalizando ironicamente, às vezes, como uma ideia de golpe de publicidade ou de golpe de sorte. Da mesma forma, também observamos como a palavra impeachment aparece, no interdiscurso, muitas vezes, associada negativamente à memória do impeachment do ex-presidente Collor em 1992, ao lado de outros sentidos, como o de "saída", "renúncia" ou dos sentidos de exclamações com "Fora, Dilma!", em conflito com o apelo do "Não vai ter golpe!".

Desse modo, examinamos aqui as marcas semânticas e enunciativas interpeladas pelas disputas de sentidos assumidos pelos sujeitos por meio da linguagem e no confronto entre discursos inscritos em formações discursivas atravessadas pela ideologia e pela história.

Assim, da ressaca cívica à ironia, do afastamento (para alguns) ao golpe de sorte (para outros), pudemos observar que o afastamento da ex-presidenta Dilma Rousseff comemorado por alguns representou para outros a materialização de um golpe enunciado e anunciado (sem aspas). Afinal, como analisou certa vez Pêcheux (1975), a partir do enunciado on a gagné, ressoa a inquietante pergunta: quem ganhou? (acrescentamos, com o golpe).

Portanto, das cavalarias aos tanques de guerra, do golpe de/no poder em 1964 pelos militares, às recentes e sutis tentativas de silenciamento em torno de um processo considerado (no interior de determinadas FDs) como um processo golpista contra o governo Dilma, a enunciação de golpe foi e tem sido, desse modo, retomada, (re)deslocada, atualizada e interpelada, se desdobrando discursivamente em diferentes sentidos, entre os quais, a saber: pelos protestos (na multidão), pelo voto sim, pelo voto não, pela bandeira (colorida), pelo vermelho (na camisa), pelo protesto, pelo grito, pelo áudio (transcrito), pelos clamores (da rua), pelo enunciado discursivizado ideologicamente na/pela luta.

\section{REFERÊNCIAS}

AGUIAR, F. A semântica do golpe. In: Especial 1964-2004. Carta Maior, 30/03/04. Disponível em $<\underline{\text { http://cartamaior.com.br/?/Coluna/Especial-1964-2004-br-A-semantica-do-golpe/20391> }}$ Acesso em 18.06.2016.

AUTHIER-REVUZ, J. (1982). Entre a transparência e a opacidade: um estudo enunciativo do sentido. Porto Alegre: EIPUCRS, 2004.

AUTHIER-REVUZ, J. (1984). Hétérogénéité(s) énonciative(s). Langages, v. 19, n. 73, p. 98111, 1984. Tradução brasileira: Heterogeneidade(s) enunciativa(s). Cadernos de Estudos Lingüisticos. Campinas, São Paulo: IEL/UNICAMP, n. 19, 1990, p. 25-42.

BENVENISTE, E. Problemas de Linguística Geral II. 2. ed. Campinas: Pontes, 2006 [1974]. 
BRAIT, B. Entre o semiótico e o ideológico. Bakhtiniana: Revista de Estudos do Discurso, v. 10, p. 5-26, 2015.

BOBBIO, N. Direita e esquerda: razões e significados de uma distinção política. Trad. Marco Aurélio Nogueira. São Paulo: Editora Unesp, 1994.

COURTINE, J-J. (1981). Análise do discurso político: o discurso comunista endereçado aos cristãos. São Carlos: Edufscar, 2009.

FIORIN, J. L. O regime de 1964: discurso e ideologia. São Paulo: Atual, 1988a.

FIORIN, J. L. Linguagem e ideologia. São Paulo: Ática, 1988b.

FOUCAULT, M. (1972). Retornar à história. In: FOUCAULT, M. Ditos e escritos vol. II - arqueologia das ciências e história dos sistemas de pensamento. Trad. Elisa Monteiro. Rio de Janeiro: Forense Universitária, 2000.

FUCHS, K. As problemáticas enunciativas: esboço de uma apresentação histórica e crítica. Trad. Leticia M. Rezende. Alfa, São Paulo, v. 29, p. 111-129, 1985.

GUIMARÃES, E. R. J. Língua e enunciação. Cadernos de Estudos Lingüísticos. Campinas, São Paulo: IEL/UNICAMP, n. 30, p. 99-103, 1996.

GUIMARÃES, E. R. J. Semântica do acontecimento: um estudo enunciativo da designação. Campinas: Pontes, 2002.

GUIMARÃES, E. R. J. Os limites do sentido: um estudo histórico e enunciativo da Linguagem. Campinas: Pontes, 2003.

HENRY, P. Constructions relatives et articulations discursives. In: Analyse du discours, langue et ideologies. Langages, v. 9, n. 37, p. 81-98, 1975. Disponível em $<$ http://www.persee.fr/doc/ lgge 0458-726x 1975 num 937 2613\#lgge 0458-26X 1975 num 937 T1 $00900000>$ Acesso em 17.06.2016.

LYOTARD, A. Le différend. Paris: Minuit, 1983.

NASCIMENTO, E. Metáforas da crise: entre o discurso e a hipertextualidade no jornalismo on-line. Linguagem em (Dis)curso (online), v. 16, n. 2, p. 329-352, 2016. Disponível em < http://dx.doi. org/10.1590/1982-4017-160208-4715 > Acesso em 02.08.2017.

OLIVEIRA, H. A heterogeneidade constitutiva do sujeito (e de seu discurso) no filme Narradores de Javé. Anais da III Jornada Nacional de Linguística e Filologia da Língua Portuguesa. Círculo Fluminense de Estudos Filológicos e Linguísticos, 5 de novembro, 2008.

ORLANDI, E. Análise de discurso: princípios e procedimentos. Campinas: Pontes, 1990.

ORLANDI, E. As formas do silêncio. Campinas: Editora Unicamp, 1992.

PÊCHEUX, M. (1969). Análise automática do discurso. Trad. Eni de Lourdes Puccinelli Orlandi. In: GADET, F.; HAK, T. (orgs). Por uma análise automática do discurso: uma introdução à obra de Michel Pêcheux. Campinas: Editora Unicamp, p.61-162, 1990. 
PÊCHEUX, M. (1975). Semântica e discurso: uma crítica à afirmação do óbvio. Trad. Eni Puccinelli Orlandi et al. Campinas: Editora Unicamp, 1988.

PÊCHEUX, M. (1983). Discurso: estrutura ou acontecimento? Trad. Eni Puccinelli Orlandi. Campinas: Pontes, 1990.

PORTELA, J. C. Semântica de "golpe". In: Aula conjunta "O discurso político: questões de língua e sociedade". UNESP/FCLAr, 23.05.2016. Disponível em $<$ https://www.academia. edu/25661235/Sem\%C3\%A2ntica_de_golpe_> Acesso em 17.06.2016.

POSSENTI, S. Questões para analistas do discurso. São Paulo: Parábola Editorial, 2009.

POSSENTI, S. (2016a). Golpe, Golpes. In: Blog do Sírio, 05.05.2016. Disponível em < https:// blogdosirioblog.wordpress.com/2016/05/05 $>$ Acesso em 06.05.2016a.

POSSENTI, S. (2016b). Golpe? In: Blog do Sírio, 07.04.2016. Disponível em < https://blogdosirioblog. wordpress.com/2016/04/07/golpe > Acesso em 09.04.2016b.

POSSENTI, S. Diferenças condensadas em palavras. Revista de Estudos da Linguagem. Belo Horizonte, v.26, n.3, p. 1075-1099, 2016c.

ZOPPI FONTANA, M. G. Acontecimento, arquivo, memória: às margens da lei. Leitura. Revista do Programa de Pós-Graduação em Letras (UFAL), n. 30, p. 88-105, 2004. 